\title{
Sustainable forest use in Brazilian extractive reserves: Natural regeneration of Brazil nut in exploited populations
}

\author{
L.H.O. Wadt ${ }^{a}$, K.A. Kainer, ${ }^{b, c, *}$, C.L. Staudhammer ${ }^{b}$, R.O.P. Serrano ${ }^{d}$ \\ ${ }^{a}$ Centro de Pesquisa Agroflorestal do Acre (Embrapa Acre), BR-364, Km 14, Rio Branco, Acre 69901-108, Brazil \\ ${ }^{\mathrm{b}}$ School of Forest Resources and Conservation, P.O. Box 110410, University of Florida, Gainesville, FL 32611, USA \\ ${ }^{\mathrm{C} C e n t e r}$ for Latin American Studies, Tropical Conservation and Development Program, University of Florida, Gainesuille, FL 32611, USA \\ ${ }^{\mathrm{d} U n i v e r s i d a d e ~ F e d e r a l ~ d o ~ A c r e ~(U F A C), ~ R o d o v i a ~ B R-364, ~ K m ~ 04, ~ R i o ~ B r a n c o, ~ A c r e ~ 69915-900, ~ B r a z i l ~}$
}

\section{A R T I C L E I N F O}

\section{Article history:}

Received 16 March 2007

Received in revised form

10 October 2007

Accepted 16 October 2007

Keywords:

Amazon

Bertholletia excelsa

Demography

Fruit fate

Managed resource protected area

Non-timber forest product

Seed harvest

\begin{abstract}
A B S T R A C T
The emergence of Brazilian extractive reserves reinforced the notion that sustainable forest use could play a central role in conservation. Brazil nut is considered a model non-timber product for promoting conservation through use. Demographic studies, however, have demonstrated differential impacts of nut harvest on Brazil nut population structure. Comparing three populations with different forest use histories, degrees of road access, and recent levels of nut harvest, we asked: (1) Are they exhibiting regeneration failure? and (2) Are seedling/sapling densities explained by adult Brazil nut structure, fruit fate and/or overall forest structure? We installed four 9-ha plots in each site to census Brazil nut trees $\geqslant 10 \mathrm{~cm} \mathrm{dbh}$, and within each plot, 36 subplots $(25 \times 25 \mathrm{~m}$ each) to quantify regeneration, overall forest structure, and open and closed fruit counts. Approximately $29-55 \%$ of fruits was unharvested, and more than $90 \%$ of these was opened by scatterhoarding dispersers. Population structure approximated a reverse-J size class distribution, with seedling densities varying from 3.2 to 5.8 individuals $\mathrm{ha}^{-1}$. We conclude that within the current harvest context, regeneration is sufficient for population persistence in our sites, at least over the medium term. The socioeconomics of sustainably managing Brazil nut is the greater challenge, involving interlinked competitive land uses, nut quality, and substantial increases in local income from harvest. Some of these challenges are being addressed in Brazil, Bolivia and Peru, providing hope that this cornerstone extractive species will continue to play a prominent role in the ecological and economic landscape of Amazonia.
\end{abstract}

(c) 2007 Elsevier Ltd. All rights reserved.

\section{Introduction}

The expansion of the IUCN (World Conservation Union) protected area classification system to include Category VI (managed resource protected areas) in 1994, underscored the limitations of relying solely on strict protected areas for global nature conservation. Category VI was created, in large part, to accommodate and recognize the emergence of Extractive Reserves (RESEX) in the Brazilian Amazon, reinforcing the growing notion that local communities could play a central role in conservation strategies through promotion of sustainable forest use (Maretti, 2005). Originating from the rubber tapper social movement in Acre, Brazil, Extractive Reserves are government-owned protected areas designated for sustain-

\footnotetext{
* Corresponding author: Address: School of Forest Resources and Conservation, 210 Newins-Ziegler Hall, P.O. Box 110410, University of Florida, Gainesville, FL 32611, USA. Tel.: +1 3528460833.

E-mail addresses: lucia@cpafac.embrapa.br (L.H.O. Wadt), kkainer@ufl.edu (K.A. Kainer), staudham@ifas.ufl.edu (C.L. Staudhammer), ropereas@gmail.com (R.O.P. Serrano). 0006-3207/\$ - see front matter @ 2007 Elsevier Ltd. All rights reserved. doi:10.1016/j.biocon.2007.10.007
} 
able extraction and conservation of renewable natural resources by resident populations with a tradition of non-timber extraction (Allegretti, 1994). The requirement of management plans within these reserves has triggered a transition from a traditional pattern of general forest exploitation to more conscious management of the ecosystem and its resources.

In the Amazon, this includes managing Brazil nut (Bertholletia excelsa) populations. This species has gradually replaced rubber as the most important commercial nontimber forest product for local populations living in RESEX Chico Mendes (Wallace, 2004; Ehringhaus, 2006), an almost one million ha reserve in the state of Acre, and other similar multiple-use reserves in the Brazilian, Bolivian and Peruvian Amazon. Brazil nut is widely recognized as a model non-timber forest product for promoting tropical forest conservation. It is solely harvested in the wild from mature forests and has enjoyed widespread and longstanding economic success in the international market. Indeed, this single species has been credited with the protection of millions of hectares of intact forest in Brazil, Bolivia and Peru (Ortiz, 2002) where its commercial harvest and marketing represents a major income source for rural and peri-urban collectors and processors (Stoian, 2005). Consequently, Brazil nut productivity has become increasingly linked with long-term reserve viability, particularly given the economic attractiveness of alternative land uses that lead to forest conversion, such as cattle production.

Long-term success of an extractive product depends not only on its economic viability, but also on the ecological resilience of the target species to exploitation. Brazil nut also enjoys some advantages in this dimension of sustainability. Seeds are the part of the plant that is harvested, and in some trees, very high levels of fruit and seed collection may permit population persistence over decades (Ticktin, 2004). As larger seed quantities are collected, however, the number of remaining seeds may not be adequate to ensure sufficient recruitment, potentially resulting in reduced seedling numbers (Peters, 1996). In addition to these human interventions, B. excelsa recruitment is intimately linked to the forest rodent Dasyprocta spp., or agoutis. Humans and agoutis are practically the only two species capable of opening the hard B. excelsa fruits, and are therefore key determinants of Brazil nut fruit fate, and ultimately natural regeneration. Still, the long-lived nature of $B$. excelsa, with seed production occurring over most of its multi-century lifespan, is considered to provide medium-term demographic insurance against nut overexploitation (Zuidema, 2003). Recent empirical studies have demonstrated differential impacts of nut harvest on $B$. excelsa population structure. In Bolivia, 93\% collection rates appeared to have minimal effect on regeneration, with populations retaining a healthy demographic structure (Zuidema and Boot, 2002). While a study across the entire Amazon basin reported that more intensively collected populations over longer periods of time (decades), generally in Eastern Amazonia, showed clear signs of regeneration failure (Peres et al., 2003). In the latter study, small Brazil nut trees $(10-60 \mathrm{~cm}$ in diameter at breast height - dbh) were uncommon to rare in five of 22 populations surveyed, and virtually absent in another three, corresponding to stands in which seeds had been moderately to persistently harvested, respectively. This basin-wide study demonstrated that interlinked variables such as differences in site accessibility, Brazil nut commercialization efforts, and harvest intensity could influence B. excelsa regeneration success. This study also attained widespread dissemination in scientific and popular media, raising the possibility that an imminent demographic collapse may be threatening this cornerstone of the Amazonian extractive economy.

Contributing to this debate, we sought to examine demographic structures of three western Amazonian B. excelsa populations in Category VI protected areas with different forest use histories, degrees of road access, and recent levels of nut harvest. These three Brazil nut populations form part of the same regional metapopulation. Our research questions were twofold: (1) Are exploited populations in these sites exhibiting regeneration failure? and (2) To what extent are B. excelsa seedling/sapling densities explained by factors such as adult B. excelsa structure, fruit fate and/or overall forest structure?

We expected comparatively greater seedling and sapling densities in sites characterized by greater numbers of reproductive adults and lower levels of nut harvest. Conversely, we anticipated that sites with greater road access and other heightened forest development activities, especially when related to intensified Brazil nut harvesting and processing, would have reduced seedling and sapling densities.

\subsection{Study species}

Bertholletia excelsa occurs throughout much of the terra firme forests in the Amazon basin. Within our study region, individuals are distributed rather randomly (Wadt et al., 2005a), though others have widely reported that adults are concentrated in groves (Müller et al., 1980; Mori and Prance, 1990; Peres and Baider, 1997). At maturity, B. excelsa is a very large emergent tree, and can be long-lived, with three individuals $>45 \mathrm{~cm}$ dbh radiocarbon-dated as older than 650 years (Vieira et al., 2005). Seed development only occurs through obligatory out-crossing (O'Malley et al., 1988), pollinated principally by large-bodied bees, especially Euglossinae (Prance, 1976; Nelson et al., 1985). Fruit maturation takes 14 months, resulting in a hard, large round fruit $(10-16 \mathrm{~cm})$ that falls during the rainy season (December through February in our study region). Complete decomposition of the woody fruits takes approximately three years (Zuidema, 2003; personal observations). Individual trees show considerable year-to-year variation in fruit production, though production of entire populations seems fairly constant between years (Zuidema, 2003; Kainer et al., 2007). The 8-26 large $(\sim 3.5-5 \times 2 \mathrm{~cm})$ seeds (or nuts) remain inside the fallen fruits until extraction by humans or other animals, with the scatterhoarding rodent, agouti, playing an additional, instrumental role in seed dispersal and burial. Another rodent, Myprocta sp. (acouchy), can also open B. excelsa fruits, but is a negligible contributor to seed predation and dispersal. Controlled seed storage experiments have demonstrated that $B$. excelsa seeds exhibit dormancy, likely due to combined seed coat dormancy and a second endogenous mechanism (Kainer et al., 1999). Müller (1981) reported that untreated seeds initiate germination between 12 and 18 months. While B. excelsa seeds do not require light to germinate, the species is considered gap-opportunistic (Mori and Prance, 1990). Specifically, Myers et al. (2000) 
reported that while seedlings (individuals $<1.3 \mathrm{~m} \mathrm{ht}$ ) occurred in a range of gaps sizes and in the forest understory, saplings (individuals $>1.3 \mathrm{~m} \mathrm{ht}$ and $<10 \mathrm{~cm}$ dbh) only occurred in gaps $>95 \mathrm{~m}^{2}$, suggesting a relationship between species persistence and light availability. Finally, planted seedlings in small forest gaps near our study sites exhibited average height growth rates of approximately $20 \mathrm{~cm} \mathrm{yr}^{-1}$ (Kainer et al., 1998).

\subsection{Brazil nut exploitation history}

Since 1633 when Brazil nuts were first exported to Europe, commercial exploitation of B. excelsa seeds centered historically in Eastern Amazonia, attaining broad economic significance in this region in the mid-1800s (de Souza, 1963). Once ports opened in Manaus in 1866, exploitation and commercialization of Brazil nut expanded dramatically throughout Amazonia (de Souza, 1963), and for the next century, most Amazonian forest residents relied primarily on rubber and Brazil nuts for their economic needs (Clay, 1997). Commercialization quickly became dominated by a few trading companies located in Belém at the mouth of the Amazon River, with almost all Brazil nut production exported to the international nut market (Clay, 1997).

In our study region in western Amazonia, commercial Brazil nut exploitation has historically been less intensive than in Eastern Amazonia, but similarly intertwined with commercial rubber extraction. Beginning with the first rubber boom in the late 1800s, rubber tappers were recruited to our study region from Northeastern Brazil to focus almost exclusively on rubber production. Exceptions to this rubber focus, however, did occur when Asian plantation-based rubber hit the export markets, beginning in approximately 1911 (Bakx, 1988). Tappers diversified production and developed autonomous market links, such that Brazil nut and other forest products became increasingly important economically (Bakx, 1988; de Almeida, 2002). Indeed, in the town of Xapurí located within our study region, a small Brazil nut processing plant was inaugurated in 1933. Packaged in cans and shipped in wooden crates, whole dried nuts were exported to the United States until the advent of World War II when buying was halted. Shortly afterward, the plant was destroyed in a windstorm, coinciding with a second rubber boom when tappers were again recruited to focus on rubber production - this time to support the war effort (Bakx, 1988). With the end of World War II, rubber production again relaxed and tappers pursued more diversified production. In the 1970s, with the arrival of Amazonian "development" in the Brazilian state of Acre, these same tappers organized themselves into a strong social movement, fighting for legal rights to the forested land they traditionally inhabited (de Almeida, 2002). As part of this struggle for legal and subsequently economic independence, a local agroextractive cooperative and Brazil nut processing plant were inaugurated in Acre in the 1990s, creating a Brazil nut commercialization alternative to a constrictive Belém monopoly (Michelotti, 2001). Several Brazil nut processing plants were also established in neighboring Bolivia, increasing collection pressure across the region, principally because reduced transportation prices facilitated marketing nuts from remote collection areas (Clay, 1997).

Today, harvesters in our Brazilian study region continue to reside in the forest, and nut collection is a key subsistence and market-oriented livelihood activity. Families collect after the majority of $B$. excelsa fruits have fallen in February or March, following rubber and/or Brazil nut trails that wind throughout their landholding. They typically work sections of their landholding, visiting and harvesting from each tree only once. Given individual phenological variation in fruit maturation, fruits can lie on the forest floor for several weeks, or even months, prior to collection.

\section{Materials and methods}

\subsection{Site and forest use histories}

The three sites studied, Cachoeira, Pindamonhangaba, and Filipinas, are located in the Acre River Valley of the western Brazilian Amazon in former rubber estates or seringais in Acre, Brazil. According to CNPT-IBAMA (National Center of Sustainable Development of Traditional Populations-Brazilian Institute of Renewable Natural Resources) appropriation documents, Cachoeira, Pindamonhangaba, and Filipinas encompass $24,898,14,236$, and 30,000 ha, respectively. Human population densities range from approximately 1 to 1.5 people $\mathrm{km}^{-2}$. Field sites within these seringais form a relatively straight line geographically, with Filipinas in the middle, located approximately $30 \mathrm{~km}$ from Cachoeira and approximately 35-40 km from Pindamonhangaba (Fig. 1). Each site has a distinct legal jurisdiction and history in terms of forest use, intensity of Brazil nut commercialization efforts, and accessibility.

Politically, Filipinas and Pindamonhangaba constitute part of Extractive Reserve (RESEX) Chico Mendes, an almost 1 million ha federal conservation unit under the legal jurisdiction of IBAMA. Despite similar forest extraction histories and resident cultures, Cachoeira is an "agroextractive settlement project" or PAE, under the jurisdiction of the National Institute of Colonization and Agrarian Reform (INCRA), and is legally known as PAE Chico Mendes. In all three cases, tenure is secure with little internal conflict over natural resources including Brazil nut.

The strong rubber tapper social movement of the 1970s led directly to establishment of both RESEX Chico Mendes and PAE Chico Mendes in the early 1990s. Cachoeira residents, many of them relatives of the movement leader Chico Mendes, played a prominent role in the rubber tapper struggle. Cachoeira continues to be well-known for having the strongest and most politically active associations in the region, perhaps a legacy of their strong collective mobilization (Stone, 2003). Most residents in the other two research sites only participated peripherally in the tapper movement.

Partially due to this history and high level of social organization, Cachoeira became the recipient of multiple development projects designed to improve resident quality of life and add value to extracted forest products (Michelotti, 2001). One such project designed to decentralize Brazil nut processing piloted a small plant in Cachoeira in 1991. From 1993 to 2002, Brazil nuts collected in Cachoeira were no longer taken out of the forest for processing elsewhere as was the convention, but were dehusked, dried and classified in this plant or two smaller plants that functioned at household levels (Michelotti, 2001). Another income-generating project, 


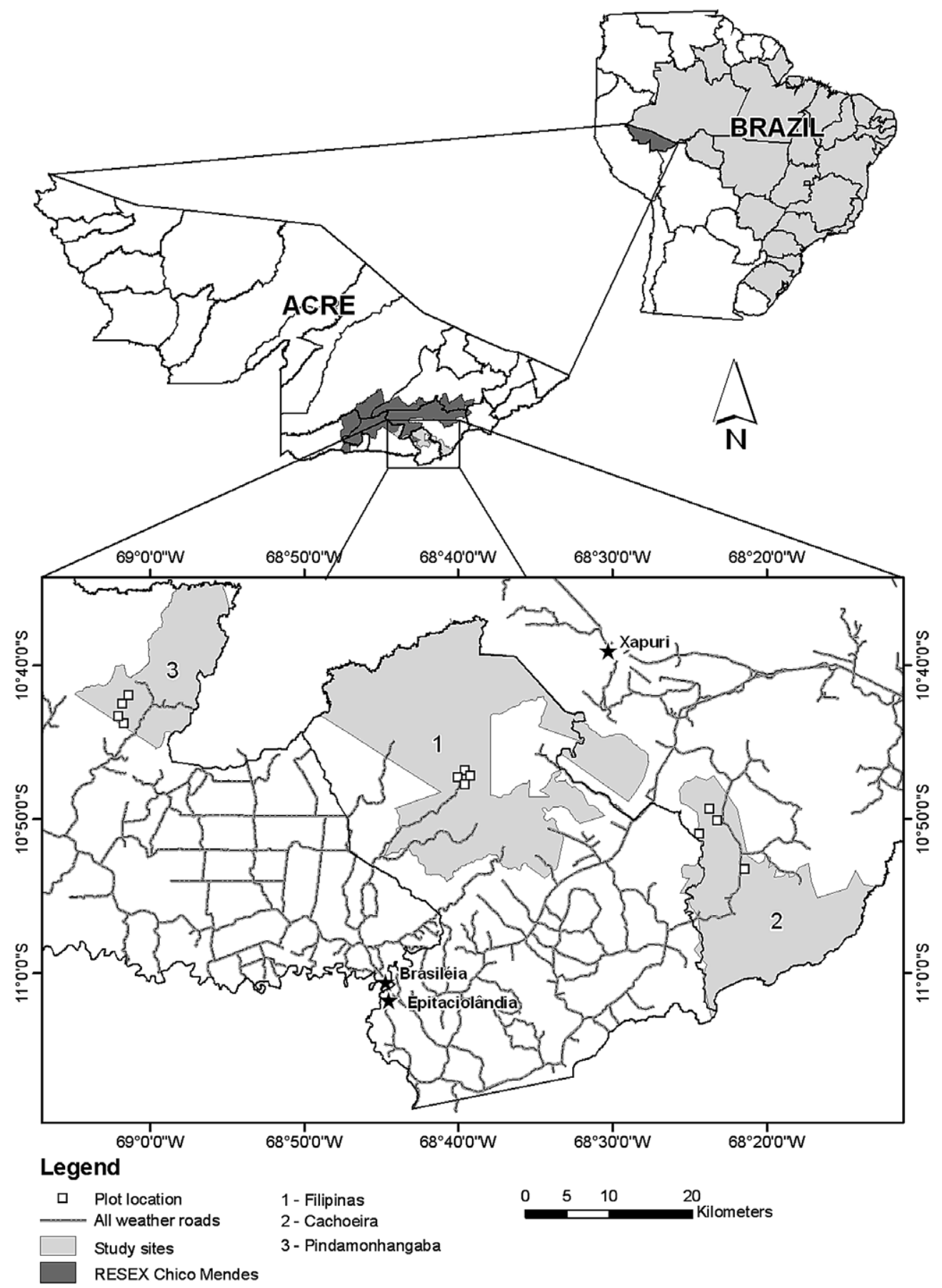

Fig. 1 - Location of study sites (Filipinas, Cachoeira and Pindamonhangaba) and four 9-ha plots within each site.

small-scale timber extraction, began in 2000, facilitated by the PAE designation of Cachoeira. In 2001, the first logs were harvested, and by 2002, the Cachoeira timber operation had been Forest Stewardship Council-certified (Stone, 2003).

Road access also contributed to this much higher level of socioeconomic activity in Cachoeira versus the other two study sites. A feeder road was opened to Cachoeira in 1978 (Serrano, 2005) (Fig. 1). In 2001, the road was extended to the interior of the PAE, and road quality improved markedly such that it was easily passable throughout the rainy season. In contrast, a hand-made feeder road opened in Fil- ipinas in 2001, simultaneously increasing the number and variety of projects targeted to this community for diversifying forest-based income. By 2004, this road was improved by the local government to facilitate extraction of multiple non-timber products, including Brazil nuts. At the time of our study, no road existed to the Pindamonhangaba study site, with the nearest feeder road located approximately $1 \mathrm{~h}$ by foot. As such, there has been very little connection with alternative income projects in this site. Finally, in part due to the greater socioeconomic activity in Cachoeira, this site is characterized by a relatively greater number of trails 
suitable for pack animal travel ( $\sim 1 \frac{1}{2} \mathrm{~m}$ in width) compared to the other two sites.

\subsection{Field measurements}

At each site, four 9-ha $(300 \times 300 \mathrm{~m})$ plots were installed over an approximately 450 ha swath of mature forest, representing the forested landscape under the management regime of typically one rubber tapper family. Spatial independence of plots and fairly representative plot distribution across the forested landscape were criteria for plot site selection. Plots were censused for all B. excelsa trees $\geqslant 10 \mathrm{~cm}$ dbh in 2003 , collecting the following data for each tree: $x-y$ coordinates; dbh; presence or absence of lianas; reproductive status $(0,1)$; and crown form: (1) complete or irregular circle (perfect or good), (2) half-crown (tolerable), (3) less than half-crown (poor), or (4) one or a few branches (very poor).

Each of the 9-ha plots were subdivided into $144(25 \times 25 \mathrm{~m})$ subplots for more intensive sampling in the last quarter of 2004. Randomization was restricted such that four subplots were randomly assigned to each one of the $9 \mathrm{ha}$, resulting in 36 sampled subplots per plot. Within each subplot, all Brazil nut seedlings and saplings $(<10 \mathrm{~cm} \mathrm{dbh})$ were mapped and assigned $x-y$ coordinates. For saplings ( $>1.5 \mathrm{~m} \mathrm{ht}$ ), dbh was measured; for seedlings $(\leqslant 1.5 \mathrm{~m} \mathrm{ht})$, diameter at the base of the plant and height were measured. The following subplot-level data was also collected: number and dbh of all tree species $\geqslant 10 \mathrm{~cm}$ dbh; number of intact (unopened) Brazil nut fruits on the ground; and number on the ground opened by rodents. Given known rates of $B$. excelsa fruit decomposition, we estimate that these intact fruit counts reflect unharvested fruits produced and predated in the 2003 and 2004 fruit falls. B. excelsa trees produce a more or less continuous pattern of fruit production at the population level - a phenomenon which has contributed to the high commercial success of Brazil nut over the last half century; the 2003 and 2004 harvest seasons were no different (Kainer et al., 2007). Further, assuming growth rates of $20 \mathrm{~cm} \mathrm{yr}^{-1}$ for young B. excelsa seedlings in forest (Kainer et al., 1998), we assume that only seedlings $\leqslant 40 \mathrm{~cm}$ ht can be attributed to these 2003 and 2004 fruits falls.

To predict the number of fruits produced by each reproductively mature B. excelsa tree, we applied an equation developed from a previous B. excelsa fruit production study in one of the three study sites (Kainer et al., 2007). These production calculations incorporated reproductive status, dbh, liana load, and crown form. Although the model developed also used measured tree-level values of soil phosphorous (P) and cation exchange capacity (CEC), these individual tree data were not available in our current study. We considered these soil variables to be relatively similar between sites, and therefore, used average values for $\mathrm{P}$ and $\mathrm{CEC}$ from the previous fruit production study.

The number of closed plus opened fruits per reproductively mature tree per ha was calculated as an indicator of collection intensity, since this total represented uncollected fruits remaining in the forest after harvest by humans. Using similar logic, the percent fruits remaining in the forest and opened by rodents (number of opened fruits per reproductively mature tree divided by number of opened plus closed fruits per reproductively mature tree) was considered an indicator of predator/disperser activity.

\subsection{Data analyses}

We used various models to test whether the multiple measured and calculated variables differed by site, using SAS for all data analysis (Version 9.1, SAS Institute, 2004). Linear mixed models (estimated with PROC MIXED) were appropriate for normally distributed variables; however, many of the tree and stand attributes measured and calculated were based on count data, making them more appropriately described by generalized linear mixed models (GLMM, estimated with PROC GLIMMIX). For count data, GLMMs using Poisson-distributed response variables were investigated; for measures derived from counts (e.g., number of closed plus opened fruits per reproductively mature tree per ha), GLMMs using the continuous counterpart of the Poisson, the gamma distribution, were investigated. All model results were compared using Akaike's Information Criteria (AIC; Quinn and Keough, 2002), and by visual examination to test normality and homoscedastic model residuals. Various iterations of interactions and covariates were tested to improve (lower) the AIC value as recommended by Burnham and Anderson (2002). Model building also was explored using conventional methods whereby all appropriate covariates were tested and non-significant ones were dropped sequentially until only those which were significant remained. Results of these two model building methods were almost identical, and we only report results obtained through the conventional method. Because some data were collected on a plot-level ( 9 ha area) basis, many statistical tests could only be performed with twelve observations, which led to relatively low statistical power.

For seedling and sapling densities, two GLMMs, one with plot-level data and a second with subplot-level data, were both tested. Despite the coarse nature of the first plot-level GLMM model, normality was attained and model residuals were homoscedastic. Because model residuals were over-dispersed at zero density with the second GLMM model, we further tested the applicability of a zero-inflated Poisson model (ZIP, Hall, 2000). This ZIP model produced identical results to the more coarse-scale GLMM model, and thus we report only the latter results.

Differences in B. excelsa distributions were also examined using non-parametric tests and spatial statistics. Using the SAS procedure PROC LIFETEST, Wilcoxon and Log-Rank statistics were computed to compare dbh and height distributions and to evaluate significant forest-level covariates with respect to these distributions. Because the log-rank test places more weight on larger values in the distributions, whereas the Wilcoxon test places more weight on smaller values (Peto and Peto, 1972), differences in the results of these tests can suggest that the effects of these covariates vary over tree size. Since a previous study had demonstrated that trees in the 100-150 cm dbh size class range were consistently the best producers (Kainer et al., 2007), we used GLMMs to test for site differences in number of reproductive adults in four different sub-adult/adult size classes ( $<50 \mathrm{~cm}, 50-100 \mathrm{~cm}, 100-150 \mathrm{~cm}$, and $>150 \mathrm{~cm}$ ).

Spatial dispersion of seedlings and opened fruits relative to reproductively mature trees was tested using the method 
described by Hamill and Wright (1986). In each of the three sites, this analysis was applied independently to each of the four 9-ha plots, without consideration to reproductively mature trees outside plot borders. The analysis tested the null hypothesis that the locations of seedlings and opened fruits were distributed randomly compared to those of adult trees.

\section{Results}

Summary results based on all 9-ha plots in the three sites revealed general patterns in the structure of the studied B. excelsa metapopulation. Densities of all Brazil nut trees $\geqslant 10 \mathrm{~cm}$ $\mathrm{dbh}$ varied between 0.7 and 2.7 individuals $\mathrm{ha}^{-1}$. The percentage of these individuals that was reproductively mature was approximately $65 \%$, with densities of this subset declining to $0.6-1.9$ individuals $\mathrm{ha}^{-1}$. Of the predicted fruits per site, approximately $29-55 \%$ were left unharvested. Of these, more than $90 \%$ was opened by rodents in all sites. Finally, densities of seedlings ( $<1.5 \mathrm{~m} \mathrm{ht}$ ) varied between 1.3 and 12.4 individuals ha ${ }^{-1}$; and of saplings, between 0 and 3.2 individuals ha ${ }^{-1}$. More detailed comparative results between sites follow.

\subsection{Forest structure}

Forest structure differences were detected by site (Table 1). Basal area of all tree species $>10 \mathrm{~cm}$ dbh was different $(P=0.0028)$, with Cachoeira having higher forest basal areas than both Filipinas $(P=0.0029)$ and Pindamonhangaba

\section{Table 1 - Means and standard errors of forest structure} values

\begin{tabular}{lcc} 
Site & Basal area $\left(\mathrm{ha}^{-1}\right)$ & Trees $\left(\mathrm{ha}^{-1}\right)$ \\
\hline Filipinas & $20.5 \pm 1.0^{\mathrm{b}}$ & $399.9 \pm 25.4$ \\
Cachoeira & $27.4 \pm 1.0^{\mathrm{a}}$ & $366.8 \pm 25.4$ \\
Pindamonhangaba & $23.2 \pm 1.0^{\mathrm{b}}$ & $450.8 \pm 25.4$ \\
\hline \multicolumn{2}{l}{ See text to exact levels of significance for each variable. } \\
\hline
\end{tabular}

$(P=0.0460)$. Site differences in number of trees $\mathrm{ha}^{-1}$ were less clear $(P=0.1082)$.

\subsection{Comparative Bertholletia excelsa structure}

The dbh structure and tree characteristics of Bertholletia excelsa individuals $\geqslant 10 \mathrm{~cm}$ dbh tended to differ slightly between sites (Table 2). Trees in Cachoeira tended to be much larger than those in Filipinas and Pindamonhangaba; however, tree sizes in all sites were highly variable, with coefficients of variation in excess of $55 \%$. Although the proportion of reproductively mature individuals, distribution of individuals by crown form class, and the proportion with lianas varied somewhat by site, differences were not statistically significant for any of these attributes (Table 2). Brazil nut tree densities, however, did vary by site $(P=0.0486)$, with Cachoeira having more B. excelsa trees $\mathrm{ha}^{-1}$ than Filipinas at $P=0.0567$ (Table 2). While there were no site differences when comparing reproductive adult densities, site differences were detected when reproductive adults were separated into four size classes, with statistical significance only in the $100-150 \mathrm{~cm}$ dbh size class range $(P=0.0336)$ (Table 3$)$. For this size class, Cachoeira had greater reproductive adult densities than Filipinas $(P=0.0346)$. Plot level measurements of basal area per ha and density for all tree species were also investigated as covariates in predicting reproductively mature adult densities by size class; however, neither of these variables contributed significantly and were dropped from the model.

Analyzing the shape of the Brazil nut tree and sapling size distribution (all individuals $>1.5 \mathrm{~m} \mathrm{ht}$ ), also revealed differences by site $(P<0.0001)$ (Fig. 2). Covariates used with the Wilcoxon test revealed that both forest basal area $(P<0.0001)$ and trees ha ${ }^{-1}(P<0.0001)$ were the most important variables explaining differences between tree size distributions at smaller diameters, while trees ha ${ }^{-1}(P<0.0001)$ was the only significant covariate explaining differences among size distributions at larger tree sizes as indicated by the Log-Rank test. Pairwise tests between sites revealed that all sites had signif-

\section{Table 2 - Descriptive statistics of adult $B$. excelsa trees $(\mathrm{dbh} \geqslant 10 \mathrm{~cm})$ in three sites}

\begin{tabular}{|c|c|c|c|c|c|c|c|c|c|}
\hline \multirow[t]{2}{*}{ Site } & \multirow[t]{2}{*}{$\mathrm{N}$} & \multirow{2}{*}{$\begin{array}{c}\text { Trees } \\
\mathrm{ha}^{-1}(\bar{x} \pm \mathrm{se})\end{array}$} & \multirow{2}{*}{$\begin{array}{c}\mathrm{dbh} \\
(\bar{x} \pm \mathrm{se})\end{array}$} & \multicolumn{4}{|c|}{ Proportion in crown form class } & \multirow{2}{*}{$\begin{array}{l}\text { Proportion } \\
\text { reproductive (\%) }\end{array}$} & \multirow{2}{*}{$\begin{array}{c}\text { Proportion } \\
\text { w/lianas (\%) }\end{array}$} \\
\hline & & & & $1(\%)$ & $2(\%)$ & $3(\%)$ & $4(\%)$ & & \\
\hline Filipinas & 54 & $1.5 \pm 0.2^{b}$ & $70.9 \pm 6.7$ & 80 & 9 & 11 & 0 & 61 & 35 \\
\hline Cachoeira & 89 & $2.5 \pm 0.3^{\mathrm{a}}$ & $93.0 \pm 5.2$ & 85 & 12 & 1 & 1 & 67 & 19 \\
\hline Pindamonhangaba & 78 & $2.2 \pm 0.3^{\mathrm{ab}}$ & $71.6 \pm 5.6$ & 85 & 9 & 4 & 3 & 68 & 37 \\
\hline
\end{tabular}

The only variable statistically different between sites was adult densities. See text to exact levels of significance for each variable.

\section{Table 3 - Mean numbers and standard errors of reproductive trees ha ${ }^{-1}$ by size classes}

\begin{tabular}{|c|c|c|c|c|c|}
\hline \multirow[t]{2}{*}{ Site } & \multicolumn{5}{|c|}{ Size class } \\
\hline & $<50$ & $50-100$ & $100-150$ & $>150$ & Total \\
\hline Filipinas & $0.06 \pm 0.04$ & $0.56 \pm 0.10$ & $0.17 \pm 0.12^{\mathrm{a}}$ & $0.14 \pm 0.08$ & $0.92 \pm 0.29$ \\
\hline Cachoeira & $0.06 \pm 0.04$ & $0.61 \pm 0.10$ & $0.72 \pm 0.12^{b}$ & $0.28 \pm 0.08$ & $1.67 \pm 0.29$ \\
\hline Pindamonhangaba & $0.17 \pm 0.04$ & $0.75 \pm 0.10$ & $0.39 \pm 0.12^{\mathrm{ab}}$ & $0.17 \pm 0.08$ & $1.47 \pm 0.29$ \\
\hline
\end{tabular}




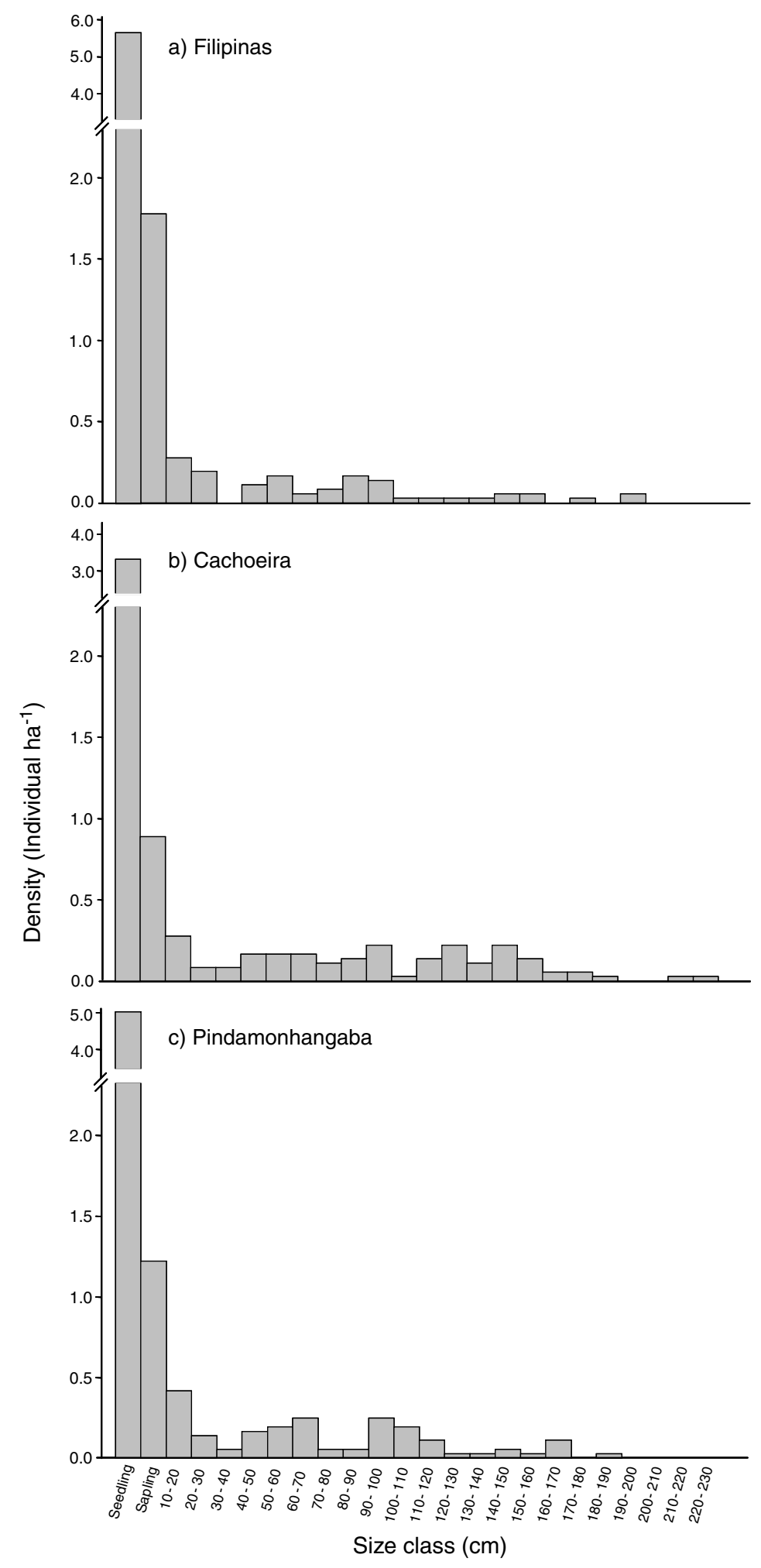

Fig. 2 - Population structure of Bertholletia excelsa for each of three sites. Seedlings are individuals $<1.5 \mathrm{~m}$ ht, saplings are individuals between $1.5 \mathrm{~m} \mathrm{ht}$ and $<10 \mathrm{~cm}$ dbh, and numeric intervals indicate dbh classes.

icantly different diameter distributions $(P<0.0001)$, with trees $\mathrm{ha}^{-1}$ an important overall explanatory variable. Forest basal area was also significant in explaining site-to-site differences specifically for Filipinas and Pindamonhangaba, and when comparing Filipinas and Cachoeira, forest basal area was only important in discriminating size distributions at smaller diameters. For Cachoeira versus Pindamonhangaba, forest basal area was not important.

Cachoeira tended to have the fewest number of seedlings ( $\leqslant 1.5 \mathrm{~m} \mathrm{ht}$ ) and saplings ( $>1.5 \mathrm{~m} \mathrm{ht}$ and $<10 \mathrm{~cm} \mathrm{dbh}$ ), although 
neither absolute seedling nor sapling densities were statistically different by site (Table 4). Differences were detected, however, when considering seedling and sapling relationships to reproductive adults present. Seedlings plus saplings per reproductive adult were statistically different by site $(P=0.0461)$ (Table 4) with Filipinas having a greater number of seedlings plus saplings than Cachoeira $(P=0.0537)$. No statistical differences by site were detected for average seedling diameters or heights, or average sapling diameters (Table 4). Seedling height distributions, however, were different between sites (Fig. 3), and both the Wilcoxon and Log-Rank tests were significant $(P=0.0043$ and $P=0.0073$, respectively), indi-

Table 4 - Mean numbers and standard errors of B. excelsa seedling ( $\leqslant 1.5 \mathrm{~m} \mathrm{ht}$ ) and sapling ( $>1.5 \mathrm{~m} \mathrm{ht}$ and $<10 \mathrm{~cm}$ dbh) attributes

\begin{tabular}{|c|c|c|c|c|c|c|c|c|c|}
\hline \multirow[t]{3}{*}{ Site } & \multicolumn{5}{|c|}{ Seedlings } & \multicolumn{4}{|c|}{ Saplings } \\
\hline & \multicolumn{5}{|c|}{ Ind. repro. } & \multicolumn{4}{|c|}{ Ind. repro. } \\
\hline & $\mathrm{N}$ & Ind. $\mathrm{ha}^{-1}$ & Tree $^{-1}$ & $\mathrm{Db}^{\mathrm{a}}$ & Height & $\mathrm{N}$ & Ind. $\mathrm{ha}^{-1}$ & Tree $^{-1 b}$ & $\mathrm{dbh}$ \\
\hline Filipinas & 52 & $5.8 \pm 1.6$ & $6.1 \pm 1.1^{\mathrm{a}}$ & $0.48 \pm 0.20$ & $0.48 \pm 0.29$ & 16 & $1.8 \pm 1.6$ & $8.4 \pm 1.4^{\mathrm{a}}$ & $4.9 \pm 3.3$ \\
\hline Cachoeira & 29 & $3.2 \pm 0.9$ & $2.0 \pm 1.1^{b}$ & $0.44 \pm 0.26$ & $0.33 \pm 0.15$ & 7 & $0.9 \pm 0.8$ & $2.6 \pm 1.4^{\mathrm{b}}$ & $5.6 \pm 1.7$ \\
\hline Pindamonhangaba & 45 & $5.0 \pm 1.4$ & $3.1 \pm 1.1^{\mathrm{ab}}$ & $0.46 \pm 0.16$ & $0.47 \pm 0.27$ & 11 & $1.2 \pm 1.2$ & $4.1 \pm 1.4^{\mathrm{ab}}$ & $2.8 \pm 2.5$ \\
\hline
\end{tabular}
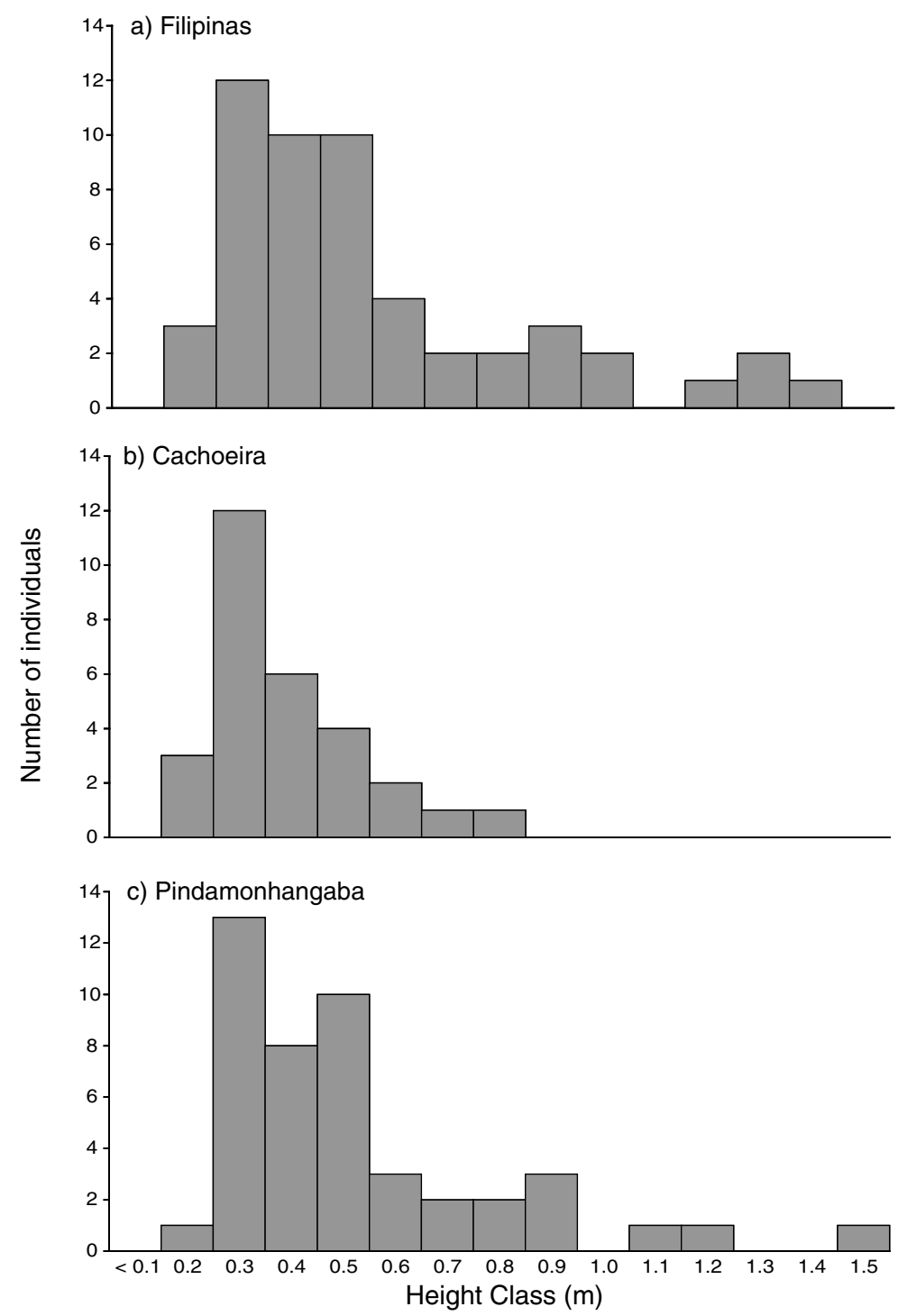

Fig. 3 - Height class distributions of seedlings (individuals $<1.5 \mathrm{~m} \mathrm{ht}$ ) for each of three sites. 
cating different distributions for both shorter and taller seedlings, respectively. Trees $\mathrm{ha}^{-1}$ of the surrounding forest was only important in explaining site-to-site differences in height distribution for shorter seedlings, but not for taller ones. Pairwise tests revealed that these results held when Cachoeira was compared to both other sites $(P=0.0017$ and $P=0.0010$ for the Wilcoxon and Log-Rank tests, respectively), while Filipinas and Pindamonhangaba were not significantly different in terms of seedling height distributions.

The pattern of relative dispersion of seedlings and opened fruits to reproductively mature trees varied between sites (Fig. 4). The distribution of seedlings in both Filipinas and Pindamonhangaba was significantly different than that expected from a hypothetical random pattern $(P=0.013$ and $P=0.003$, respectively), but seedling distribution in Cachoeira was not
$(P=0.126)$. Opened fruit distributions in all three sites were significantly different than expected from the random hypothesis $(P<0.0001)$.

\subsection{Fruit fate}

The three sites presented some differences in predicted fruit production and the fate of fruits produced (Table 5). Predicted fruit production per reproductive adult varied by site $(P=0.0102)$, with Cachoeira predicted to produce more fruits than both Filipinas $(P=0.0282)$ and Pindamonhangaba $(P=0.0518)$. Number of fruits unharvested by humans was different between sites $(P=0.0092)$, with Cachoeira having significantly more fruits $\mathrm{ha}^{-1}$ remaining in the forest than Pindamonhangaba $(P=0.0198)$ or Filipinas $(P=0.0325)$.

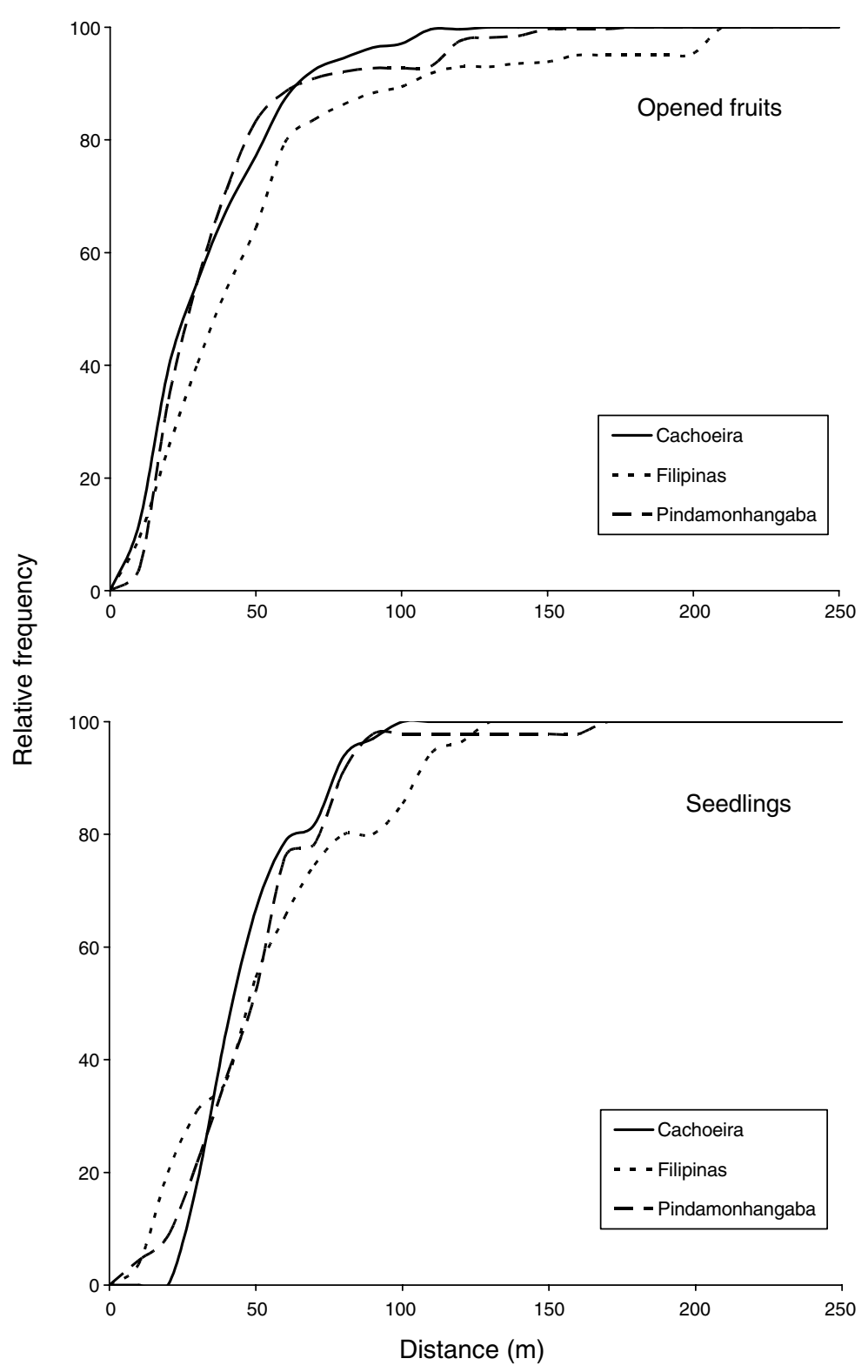

Fig. 4 - Distribution curves of opened fruits and seedlings (individuals $<1.5 \mathrm{~m} \mathrm{ht}$ ), with distances relative to reproductively mature trees. Curves represent weighted averages of all four 9-ha plots, without consideration to reproductive adults outside plot borders, in each of three sites. 


\section{Table 5 - Mean numbers and standard errors of predicted fruit production and fates of fruits produced}

\begin{tabular}{lcccccc} 
Site & $\begin{array}{c}\text { Predicted fruits } \\
\text { per reproductive tree }\end{array}$ & $\begin{array}{c}\text { Fruits left } \\
\text { in forest ha }\end{array}$ & $\begin{array}{c}\text { Fruits left in } \\
\text { forest per } \\
\text { reproductive tree }\end{array}$ & $\begin{array}{c}\text { Fruits } \\
\text { opened } \\
\text { ha }^{-1}\end{array}$ & $\begin{array}{c}\text { \% Fruits } \\
\text { opened per } \\
\text { reproductive tree }\end{array}$ & $\begin{array}{c}\text { Seedlings } \\
\leqslant 40 \mathrm{~cm} \text { ht per } \\
\text { open fruits }\end{array}$ \\
\hline Filipinas & $79.6 \pm 1.1^{\mathrm{b}}$ & $39.7 \pm 5.6^{\mathrm{b}}$ & $44.9 \pm 4.0^{\mathrm{a}}$ & $37.9 \pm 5.5^{\mathrm{b}}$ & $95.2 \pm 2.2^{\mathrm{ab}}$ & $0.11 \pm 0.03$ \\
Cachoeira & $105.6 \pm 1.0^{\mathrm{a}}$ & $70.8 \pm 8.0^{\mathrm{a}}$ & $42.5 \pm 4.0^{\mathrm{a}}$ & $64.6 \pm 7.7^{\mathrm{a}}$ & $91.0 \pm 2.2^{\mathrm{b}}$ & $0.06 \pm 0.03$ \\
Pindamonhangaba & $86.5 \pm 1.1^{\mathrm{b}}$ & $37.0 \pm 5.3^{\mathrm{b}}$ & $26.3 \pm 4.0^{\mathrm{b}}$ & $36.6 \pm 5.4^{\mathrm{b}}$ & $99.2 \pm 2.2^{\mathrm{a}}$ & $0.06 \pm 0.03$ \\
\hline See text to exact levels of significance for each variable. & & & & \\
\hline
\end{tabular}

Number of unharvested fruits per reproductive adult was also different between sites $(P=0.0195)$, indicating a greater harvest intensity in Pindamonhangaba since harvesters left far fewer fruits per reproductive adult than harvesters in Filipinas $(P=0.0299)$ and possibly Cachoeira $(P=0.0558)$.

The number of fruits opened by rodents was also different between sites $(P=0.0212)$, with the number opened in Cachoeira greater than that in Pindamonhangaba $(P=0.0442)$ and possibly Filipinas $(P=0.0565)$ (Table 5$)$. Level of predator/disperser activity, based on percent fruit opened per reproductive adult, was only different between sites at $P=0.0748$ (Table 5).

\section{Discussion}

We set out to analyze if exploited Brazil nut populations in Category VI protected areas in western Amazonia were exhibiting regeneration failure. To support this analysis, we executed a comparative study of $B$. excelsa structure in three sites distinguished by slightly different ecological and socioeconomic contexts. We also sought to understand if regeneration in these three sites, specifically seedling/sapling densities, was explained by overall forest structure, Brazil nut adult structure, and fruit fate.

\subsection{Bertholletia excelsa structure}

Our structural data from three sites do not suggest an imminent demographic collapse of our Brazil nut study populations. Population structure in all three sites was roughly represented by a reverse-J size class distribution, having greater representation in smaller size classes, and slightly declining proportional representation with increasing size (Fig. 2). This structure suggests healthy demographic populations whereby mortality of larger trees would likely result in growth of smaller individuals (Peters, 1996). Similar size-class structures were reported for two sites in neighboring Bolivia (Zuidema and Boot, 2002) and one nearby in Brazil (Viana et al., 1998). On the other hand, our observed demographics contrast sharply with size class structures of multiple B. excelsa populations $\geqslant 10 \mathrm{~cm}$ dbh considered to be consistently and intensively harvested over decades (Peres et al., 2003). When comparing patterns of mean tree dbh and juvenile (10$60 \mathrm{~cm} \mathrm{dbh}$ ) abundance of our study populations (Fig. 5) with those of Peres et al. (2003), none of our sites would be classified as moderately or persistently harvested when viewed through their decadal harvest lens. Indeed, both Filipinas and Pindamonhangaba would be classified as "unharvested", and Cachoeira would be classified as "lightly harvested", de-
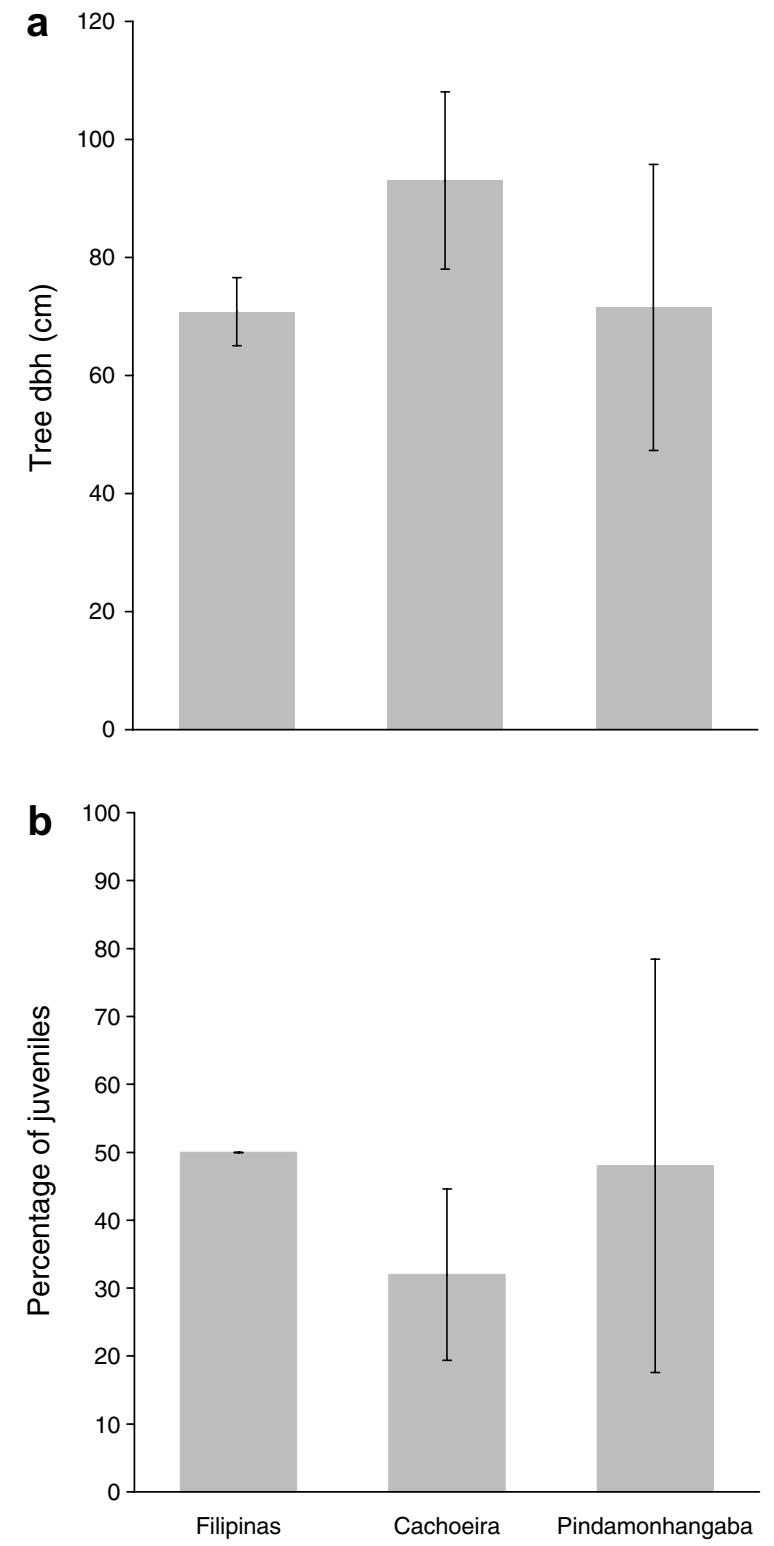

Fig. 5 - Mean ( \pm standard deviation) tree $\mathrm{dbh}(\mathrm{cm})$ (a) and percentage of Brazil nut juveniles (trees $10-60 \mathrm{~cm} \mathrm{dbh}$ ) (b) in each of three study sites.

spite our calculated two-year harvest intensities of $45 \%$, $71 \%$, and $60 \%$, respectively in these sites. It is possible that Brazil nut fruits in Cachoeira were harvested more intensively in recent history relative to the other two sites, due to road access since 1978 and in-forest nut processing between 1993 
and 2002. Certainly, all three sites have experienced some level of commercial exploitation over the decades since rubber tapper occupation in the late 1800s, with exploitation intensifying between rubber booms and becoming increasingly important post-World War II.

Seedling densities ( $\leqslant 1.5 \mathrm{~m} \mathrm{ht} \mathrm{ha}^{-1}$ ) in our three study sites were almost tenfold lower $\left(5.8,3.2\right.$, and 5.0 seedlings ha ${ }^{-1}$, respectively) than those reported for two Bolivian sites with a slightly lower (<1.4 $\mathrm{m} \mathrm{ht}$ ) cutoff (approximately 48 and 24 seedlings ha ${ }^{-1}$, respectively) (Zuidema and Boot, 2002). In part, this difference can be attributed to the season in which seedlings were counted. They measured seedling densities during the rainy season, while our seedlings were enumerated at the end of the dry season. Whereas seed germination takes place during the rainy season, the first dry season can bring mortality rates of $65 \%$ for new recruits (Zuidema and Boot, 2002). These methodological considerations, however, do not account for all differences between their study sites and ours. Zuidema (2003) reports highly contrasting values of 8 and 40 seedlings $(<70 \mathrm{~cm} \mathrm{ht}$ ) per reproductive adult for the Bolivian populations, while we found a range of 2.0-6.1 seedlings ( $\leqslant 150 \mathrm{~cm} \mathrm{ht}$ ) per reproductive adult in our sites. Further reasons for these density differences between their sites and ours remain unknown.

\subsection{Explaining seedling/sapling densities}

Cachoeira and Pindamonhangaba had approximately $1 \frac{1}{2}$ times more individuals $\geqslant 10 \mathrm{~cm}$ dbh than Filipinas. Cachoeira in particular, also tended to have a greater proportion of these individuals free of lianas with good crown forms, attributes correlated with enhanced fruit production (Kainer et al., 2006). Further relating these densities to fruit production potential, Cachoeira also had more than 4 times the number of trees in the most productive size class $(100-150 \mathrm{~cm} \mathrm{dbh})$ versus that of Filipinas, and twice as many in the next most productive size class ( $>150 \mathrm{~cm}$ dbh). Additionally, based on a treelevel fruit production model, B. excelsa adults in Cachoeira were predicted to produce significantly more fruits per reproductive tree than both Filipinas and Pindamonhangaba (106 versus 80 and 86 , respectively). In sum, given these adult structural characteristics, trees in the Cachoeira study plot would be expected to produce much higher fruit levels than Pindamonhangaba and Filipinas (Table 6, Columns 1-2).

What was the fate of these fruits? Based on counts of fruits remaining in the forest and predicted fruit production estimates, we calculate that between $45 \%$ (Filipinas) and $71 \%$ (Pindamonhangaba) of fruits produced in each site were harvested by residents for the commercial Brazil nut market or home consumption (Table 6). These values are much lower than the average $93 \%$ of Brazil nut fruits harvested, reported by Zuidema and Boot (2002) in their Bolivian sites. These very different proportions by country may be due to complex differences in Brazil nut harvest systems and economies. Collectors in Bolivia tend to harvest more intensively, partially due to insecure resource tenure; collectors harvest as soon as fruits fall and visit each tree more than once throughout the harvest season (Marco Antonio Albornoz, personal correspondence). Based on percentage of fruits left in the forest, collection intensity in Pindamonhangaba was greater than those of the other two sites (29\% versus $40 \%$ in Filipinas and $55 \%$ in Cachoeira). Harvesters in Pindamonhangaba have far less access to alternative income projects, but whether this accounts for more intensive Brazil nut harvest remains speculative.

Given the comparatively low Brazil nut collection intensity by Cachoeira residents and the much greater fruit production levels in this site, almost twice the number of fruits were left in the forest than were left in either Filipinas or Pindamonhangaba, and almost twice the number were opened by the scatterhoarding agouti (Table 6). It was Cachoeira, however, that had a significantly lower percentage of fruits left in the forest (unharvested by humans) that were opened (by rodents) per reproductive adult (91\%), compared to Pindamonhangaba (99\%) and Filipinas (95\%), respectively. This lower percentage of fruits opened in Cachoeira could be due to the absolute higher abundance of fruits in this site, potentially leading to predator satiation (Janzen, 1971). Using methodologies similar to ours in Bolivia, Zuidema and Boot (2002) reported that only approximately $50 \%$ of the fruits left in the forest were opened by agouti. Nonetheless, in our sites and in Bolivia, the proportion of seeds cached from these opened fruits (and therefore more likely to germinate) versus consumed, is unknown. Controlled Brazil nut seed placement

Table 6 - Linkages between reproductive trees, fruit fates, and seedlings

\begin{tabular}{|c|c|c|c|c|c|c|c|c|c|}
\hline \multirow[t]{2}{*}{ Site } & \multirow[t]{2}{*}{$\begin{array}{c}\text { Repro. } \\
\text { trees }\end{array}$} & \multirow[t]{2}{*}{$\begin{array}{l}\text { Predicted } \\
\text { fruits }\end{array}$} & \multicolumn{2}{|c|}{$\begin{array}{l}\text { Fruits left } \\
\text { in forest }^{\mathrm{a}}\end{array}$} & \multicolumn{2}{|c|}{$\begin{array}{l}\text { Predicted fruits } \\
\text { harvested }^{\mathrm{b}}\end{array}$} & \multirow[t]{2}{*}{$\begin{array}{c}\text { Fruits } \\
\text { opened }\end{array}$} & \multirow[t]{2}{*}{$\begin{array}{l}\text { Seedlings } \\
<40 \mathrm{~cm}^{\mathrm{d}}\end{array}$} & \multirow[t]{2}{*}{$\begin{array}{l}\text { Seedlings }<40 \mathrm{~cm} \text { per } \\
\text { fruits left in forest }\end{array}$} \\
\hline & & & $\mathrm{N}$ & $\%$ & $N$ & $\%$ & & & \\
\hline Filipinas & 33 & 2627 & 1432 & 55 & 1195 & 45 & 1368 & 100 & 0.07 \\
\hline Cachoeira & 60 & 6336 & 2552 & 40 & 3784 & 60 & 2332 & 84 & 0.03 \\
\hline Pindamonhangaba & 53 & 4584 & 1332 & 29 & 3252 & 71 & 1320 & 88 & 0.07 \\
\hline
\end{tabular}

Numbers apply to 36 ha in each site. Absolute fruit and seedling counts, however, were based on 9-ha surveys, and these measured values were multiplied by 4 to attain the same 36 -ha scale.

a Multiplied absolute count numbers by 4 .

b Predicted fruits - fruits left in forest.

c Multiplied absolute count numbers by 4 .

d Multiplied absolute count numbers by 4 .

e Seedlings $<40 \mathrm{~cm}$ divided by fruits left in the forest. 
studies by Peres and Baider (1997) in Brazil, and by Bouwman and van Dijk (1999) in Bolivia, both reported approximately $50 \%$ seed burial, although neither study accounted for large proportions of experimentally placed seeds $(>40 \%)$.

Given Cachoeira's comparatively higher fruit production levels, greater absolute numbers of fruits left in the forest, and greater absolute numbers of fruits opened by scatterhoarding rodents, did this translate to higher seedling densities? Although not statistically significant, Filipinas and Pindamonhangaba had many more seedlings ha ${ }^{-1}$ than Cachoeira (5.8 and 5.0 versus 3.2). When considering seedling densities in relation to the number of reproductive adults in each site, this difference was even more dramatic with Cachoeira having statistically lower seedling levels per reproductive adult than Filipinas (1.97 versus 6.10). These seedlings, however, cannot all be attributed to our fruit counts from 2003 and 2004. Given early growth rates of $20 \mathrm{~cm} \mathrm{yr}^{-1}$ for young $B$. excelsa seedlings in forest (Kainer et al., 1998), only seedlings $\leqslant 40 \mathrm{~cm}$ ht fit that criteria. Applying this logic, plot-level estimates indicate that the three sites had similar absolute seedling levels of small seedlings $(100,88$, and 84 seedlings $\leqslant 40 \mathrm{~cm}$ ht per 36 ha in Filipinas, Pindamonhangaba and Cachoeira, respectively) attributable to our 2003 and 2004 fruit counts (Table 6). When considering levels of fruits left unharvested on the forest floor, however, for every 1000 fruits left in Cachoeira, we calculated that only 33 seedlings $\leqslant 40 \mathrm{~cm}$ ht would be established. This is substantially lower than the 66 and 70 seedlings $\leqslant 40 \mathrm{~cm}$ ht calculated for Pindamonhangaba and Filipinas, respectively (Table 6, last column).

This suggests that some condition(s) is/are absent in Cachoeira to facilitate germination and early seedling survival when compared to Filipinas and Pindamonhagaba. Seed release from fruits by agouti is not implicated; Cachoeira had many more fruits opened per hectare than either of the other two sites (65 versus 38 and 37) (Table 5). We know very little about seed fate after fruit release, however, including proportions of released seeds that were consumed or cached. Perhaps more seeds were consumed and subsequently fewer buried by agoutis in Cachoeira. Recent comparative research on Dasyprocta fuliginosa densities, however, provides some evidence to the contrary; Rosas (2006) reported that Cachoeira had fewer agoutis than at least Filipinas [1.63 \pm 0.47 and $2.78 \pm 0.15(\bar{x} \pm \mathrm{sd})$ individuals $\mathrm{km}^{-2}$, respectively]. Another potential bottleneck is loss of seed viability. Brazil nut seeds exhibit dormancy (Müller, 1982) with viability declining drastically when seeds are not kept under moist conditions throughout the dormancy period (Figueirêdo et al., 1990). Indeed, Kainer et al. (1999) found that $5 \frac{1}{2}$ months of consistently moist storage facilitates germination. Although not measured, our Cachoeira sites appeared to be comparatively drier than the other two. In sum, while unable to substantiate mechanisms, it is clear that during the study period (2003 and 2004), Cachoeira had fewer small seedlings established despite much greater levels of fruit production.

How did recruitment fare prior to 2003? Densities of seedlings $>40 \mathrm{~cm}$ ht and all saplings suggest that $B$. excelsa recruitment in Cachoeira prior to 2003 was also more limited than the other two sites. Total counts of seedlings $>40 \mathrm{~cm}$ ht $(8$, 23 and 27 in Cachoeira, Pindamonhangaba and Filipinas, respectively) (Fig. 3) would roughly correspond to the period from 1997 to 2002, while sapling densities (individuals $>1.5 \mathrm{~cm} \mathrm{ht}$ and $<10 \mathrm{~cm} \mathrm{dbh}$ ) of 0.9, 1.2, and 1.8 in Cachoeira, Pindamonhangaba and Filipinas, respectively (Table 4, Fig. 2) would roughly correspond to several years prior to 1997. These estimated dates certainly coincide with the time frame when Cachoeira housed a small Brazil nut processing plant which theoretically, could have stimulated greater local harvest intensities. Another plausible explanation for site disparities in these size classes (individuals $>40 \mathrm{~cm}$ ht and $<10 \mathrm{~cm}$ $\mathrm{dbh}$ ) could be differences in light availability. While the substantial reserves of large seeds contribute to enhancement of seedling persistence (Moles and Westoby, 2004), young seedlings (such as Brazil nut individuals $>40 \mathrm{~cm} \mathrm{ht}$ ) increasingly become dependent on external resources such as light. Gap size findings by Myers et al. (2000) clearly suggested a strong relationship between Brazil nut seedling/sapling persistence and potential light availability. In our study, forest basal area was significantly higher in Cachoeira than in Filipinas or Pindamonhangaba (Table 1), and perhaps lower light levels below the canopy contributed to significantly lower numbers of larger seedlings and saplings in Cachoeira. Furthermore, this greater forest basal area in Cachoeira can be partially attributed to the presence of larger and more Brazil nut adults than the other two sites, with Cachoeira demonstrating a tendency $(P=0.1319)$ to have a greater proportion of its forest basal area dominated by $B$. excelsa (8.0 versus $5.3 \%$ and $4.4 \%$ ). In contrast, Filipinas and even Pindamonhangaba seem to be younger Brazil nut stands, with smaller and less numerous adults and greater numbers of Brazil nut seedlings and saplings. Indeed, we question to what extent the extremely large, dominant, long-lived B. excelsa is driving overall forest structure. It seems plausible that despite recent differences in Brazil nut-agouti-human dynamics, perhaps the B. excelsa adult population structure evolved over centuries is having a greater impact on conspecific seedling and sapling densities than more current events.

In sum, our comparative data across sites indicate some differences in overall forest structure and Brazil nut adult structure, fruit fate, and regeneration. While we found some linkages between site conditions (both socioeconomic and ecological) and demographic structures, we could not fully explain observed differences in Brazil nut seedling/sapling densities across sites. Vander Wall et al. (2005) state that post-secondary dispersal processes are challenging to quantify and are often understudied, limiting our understanding of plant recruitment. We concur, noting that further research of both short- and long-term ecological processes combined with a more nuanced understanding of the role of humans in Brazil nut fruit fate and regeneration would improve understanding of species dynamics.

\subsection{Conservation and management implications}

While some conservation advocates continue to call for strict limitations of human activity in and around protected areas (Terborgh, 1999; Oates, 1999), most have come to the conclusion that sustainable use has a significant role to play in nature conservation globally (Brechin et al., 2002; Nepstad et al., 2002; Heywood and Iriondo, 2003). Brazil nut is often cited as one example of sustainable use such that contemporary Bra- 
zil nut collection and marketing is credited with protection of millions of hectares of intact forest in Brazil, Bolivia and Peru (Ortiz, 2002), and represents a major income source for rural and peri-urban collectors and processors in these countries (Stoian, 2005). Effects of direct seed harvest on species sustainability, however, have been questioned. Recommendations for more relaxed harvest levels, enrichment plantings for population maintenance and no-take areas have been suggested for Brazil nut populations with recent histories of more intensive exploitation (Peres et al., 2003). Our results, and those of Zuidema and Boot (2002), suggest that these measures are not necessary to sustain Brazil nut populations in our shared study region given the current harvest context. Applying matrix population models to their data, Zuidema and Boot (2002) concluded that seed removal and seedling abundance alone were not reliable indicators of overall Brazil nut population stability. Size class structures across their sites and ours suggest no immediate demographic threats currently exist to this cornerstone extractive species in our study regions. While we did detect some differences in demographic structures across our study sites, particularly in Cachoeira, we could not clearly attribute these differences to either socioeconomic or ecological factors, with causality remaining speculative.

The larger threat to $B$. excelsa sustainability is much more complex. We agree with Silvertown (2004) that the socioeconomics of sustainably managing Brazil nut is the greater challenge, involving interlinked competitive land uses, nut quality for a demanding global market, and substantial increases in local income from nut harvest and processing. In many senses, this challenge is being addressed in the tri-country border region where Brazil, Bolivia and Peru intersect - the western Amazonian region to which large-scale Brazil nut harvest has shifted from its historic hub in Pará, Brazil (Peres et al., 2003). This shift has been accompanied by a relaxation of a well-established monopoly of Brazil nut trade centered in Belém, Pará (Clay, 1997), such that Bolivia is now the largest Brazil nut exporter (Zuidema, 2003) and increasing numbers of smaller cooperatives and supportive governmental and non-governmental initiatives in this tri-country region have emerged. Best Brazil nut management practices are highlighted in extension books and pamphlets produced independently in Peru (Cardó, 2000) and western Brazil (Wadt et al., 2005b). Cross-country communications, sharing Brazil nut harvest information and marketing strategies, have also been fortified through a tri-country regional planning initiative called MAP (Madre de Dios, Peru; Acre, Brazil; and Pando, Bolivia), which has included at least four mini-MAP Brazil nut workshops over the last four years. Green, fair-trade and organic certification have also emerged (Ortiz, 2002), with Forest Stewardship Council standards published for Brazil (CBMF, 2003), Peru (CP-CFV, 2005) and Bolivia (CFV, 2006). Participatory mapping, silvicultural techniques, and other Brazil nut monitoring programs for more efficient collection and improved and sustained production have made headway in all three countries. These practical initiatives have resulted in many locally-developed management plans and have been accompanied by real gains in local Brazil nut prices. For example, Brazil nut collectors in Acre who followed these management techniques received twice the price per kilo- gram for their nuts by (Cooperativa dos Agricultores e Produtores de Epitaciolandia e Brasiléia) CAPEB in 2006 than those collectors who extracted Brazil nuts traditionally, without these practices. These socioeconomic advances provide hope that this cornerstone extractive species will continue to play a prominent role in the ecological and economic landscape of Amazonia. Similarly, these types of initiatives that link ecologically sound management with economic gains at the local level may serve as an example for other Category VI protected areas in which local communities are key actors in conserving and/or converting tropical forests.

\section{Acknowledgements}

This research was supported by grants from FINEP/MCT/CNPq in Brazil, The William and Flora Hewlett Foundation in the U.S., and the International Science Foundation, Sweden through a grant to Dr. Wadt. CNPT/IBAMA in Brazil gave permission to conduct the research in RESEX Chico Mendes. We also thank Paulo Rodrigues de Carvalho for his superior field assistance and Pieter Zuidema and anonymous reviewers for insightful comments on earlier manuscript drafts. Finally, we are most grateful to Valderi and Maria Alzenira who graciously shared their forest home.

\section{R E F E R E N C E S}

Allegretti, M.H., 1994. Reservas extrativistas: parâmetros para uma política de desenvolvimento sustentável na Amazônia. In: Arnt, R. (Ed.), O Destino da Floresta: Reservas Extrativistas e Desenvolvimento Sustentável na Amazônia. Relume-Dumará, Rio de Janeiro, Brazil, pp. 17-47.

Bakx, K., 1988. From proletarian to peasant: rural transformation in the state of Acre, 1870-1986. Journal of Development Studies 24, 141-160.

Brechin, S.R., Wilshusen, P.R., Fortwangler, C.L., West, P.C., 2002. Beyond the square wheel: toward a more comprehensive understanding of biodiversity conservation as social and political process. Society and Natural Resources 15, 41-64.

Bouwman, M., van Dijk, S., 1999. Removal and fate of Brazil nut seeds (Bertholletia excelsa) exposed in two contrasting seed densities in a Bolivian moist forest. M.Sc. Thesis, Utrecht University, Utrecht, Netherlands.

Burnham, K.P., Anderson, D.R., 2002. Model Selection and Multimodel Inference: A Practical Information-theoretic Approach, second ed. Springer-Verlag, New York, USA.

Cardó, A.A., 2000. Manejando bien tu Castañal. Asóciacion para la Conservación de la Cuenca Amazonica (AACA), Puerto Maldonado, Peru.

CBMF (Conselho Brasileiro de Manejo Florestal), 2003. Padrões de certificação do FSC-Forest Stewardship Council (Conselho de Manejo Florestal) para o manejo e exploração de populações naturais de castanha (Bertholletia excelsa), Documento Versão 4.0. IMAFLORA (Instituto de Manejo e Certificação Florestal e Agrícola), Piracicaba, SP, Brazil.

CFV (Consejo Boliviano para la Certificación Forestal Voluntaria), 2006. Estándares bolivianos para la certificación forestal de la castaña (Bertholletia excelsa). Santa Cruz, Bolivia.

CP-CFV (Consejo Peruano para la Certificación Forestal Voluntaria), 2005. Estándar para la certificación del manejo forestal com fines de producción de castaña (Bertholletia excelsa) en Perú. WWF-Peru, Puerto Maldonado, Peru. 
Clay, J.W., 1997. Brazil nuts: The use of a keystone species for conservation and development. In: Freese, C.H. (Ed.), Harvesting Wild Species: Implications for Biodiversity Conservation. The Johns Hopkins University Press, Baltimore, Maryland, USA, pp. 246-282.

de Almeida, M.B., 2002. The politics of Amazonian conservation: the struggles of rubber tappers. Journal of Latin American Anthropology 7, 170-219.

de Souza, A.H., 1963. Castanha do Pará: Estudo botânico, químico e tecnológico. Ministério da Agricultura-Serviço de Informação Agrícola, Estudos Técnicos, 23. Rio de Janeiro, Brazil.

Ehringhaus, C., 2006. Post-victory dilemmas: Land use, development, and social movement in Amazonian Extractive Reserves. Ph.D. Dissertation, Yale University, New Haven, CT, USA.

Figueirêdo, F.J.C., Duarte, M.L.R., Frazão, D.A.C., Carvalho, J.E.U., 1990. Conservação de sementes de castanha-do-Brasil sob condições controladas. Embrapa, Centro de Pesquisa Agropecuária do Trópico Úmido. Número 116, Bélem, Pará, Brazil.

Hall, D.B., 2000. Zero-inflated Poisson and binomial regression with random effects: a case study. Biometrics 56, 1030-1039.

Hamill, D.N., Wright, S.J., 1986. Testing the dispersion of juveniles relative to adults: a new analytic method. Ecology 67 (4), 952957.

Heywood, V.H., Iriondo, J.M., 2003. Plant conservation: old problems, new perspectives. Biological Conservation 113, 321335.

Janzen, D.H., 1971. Seed predation by animals. Annual Review of Ecology and Systematics 2, 465-492.

Kainer, K.A., Duryea, M.L., de Macêdo, N.C., Williams, K., 1998. Brazil nut seedling establishment and autecology in extractive reserves of Acre, Brazil. Ecological Applications 8, 397-410.

Kainer, K.A., Duryea, M.L., Malavasi, M.M., Silva, E.R., Harrison, J., 1999. Moist storage of Brazil nut seeds for improved germination and nursery management. Forest Ecology and Management 116, 207-217.

Kainer, K.A., Wadt, L.H.O., Gomes-Silva, D.A.P., Capanu, M., 2006. Liana loads and their association with Bertholletia excelsa fruit and nut production, diameter growth and crown attributes. Journal of Tropical Ecology 22, 147-154.

Kainer, K.A., Wadt, L.H.O., Staudhammer, C.L., 2007. Explaining variation in Brazil nut fruit production. Forest Ecology and Management 250, 244-255.

Maretti, C.C., in collaboration with Wadt, L.H.O., Gomes-Silva, D.A.P., Maldonado W.T.P. de V., Sanches, R.A., Coutinho, F., Brito, S. da S., 2005. From pre-assumptions to a 'just world conserving nature': the role of category VI in protecting landscapes, in Brown, J., Mitchell, N., Beresford, M. (Eds.), The Protected Landscape Approach: Linking Nature, Culture and Community. IUCN, Gland, Switzerland and Cambridge, UK, pp. 47-64.

Michelotti, F.A., 2001. Cooperativa Extrativista de Xapuri: Trajetória de Organização e Gestão. M.Sc. Thesis, Núcleo de Altos Estudos Amazônicos - NAEA, Universidade Federal do Pará, Brazil.

Moles, A.T., Westoby, M., 2004. Seedling survival and seed size: a synthesis of the literature. Journal of Ecology 93, 372-383.

Mori, S.A., Prance, G.T., 1990. Taxonomy, ecology, and economic botany of the Brazil nut (Bertholletia excelsa Humb. and Bonpl.: Lecythidaceae). Advances of Economic Botany 8, 130-150.

Müller, C.H., 1982. Quebra da dormência da semente e enxertia em castanha-do-brasil. Embrapa, Centro de Pesquisa Agropecuária do Trópico Úmido. Documentos 16, Belém, Pará, Brazil.

Müller, C.H., 1981. Castanha-do-brasil: estudos agronômicos. Embrapa, Centro de Pesquisa Agropecuária do Trópico Úmido. Documentos 1, Belém, Pará, Brazil.
Müller, C.H., Rodrigues, I.A., Müller, A.A., Müller, N.R.M., 1980. Castanha-do-Brasil: resultados de pesquisa. Embrapa, Centro de Pesquisa Agropecuária do Trópico Úmido. Miscelânea 2, $1-25$.

Myers, G.P., Newton, A.C., Melgarejo, O., 2000. The influence of canopy gap size on natural regeneration of Brazil nut (Bertholletia excelsa) in Bolivia. Forest Ecology and Management 127, 119-128.

Nelson, B.W., Absy, M.L., Barbosa, E.M., Prance, G.T., 1985. Observations on flower visitors to Bertholletia excelsa H.B.K. and Couratari tenuicarpa A.C. Sm. (Lecythidaceae). Acta Amazonica 15, 225-234.

Nepstad, D., McGrath, D., Alencar, A., Barros, A.C., Carvalho, G., Santilli, M., Vera Diaz Mdel, C., 2002. Frontier governance in Amazônia. Science 295, 629-631.

Oates, J.F., 1999. Myth and reality in the rain forest: how conservation strategies are failing in West Africa. University of California Press, Berkeley, CA, USA.

O’Malley, D.M., Buckley, D.P., Prance, G.T., Bawa, K.S., 1988. Genetics of Brazil nut (Bertholletia excelsa Humb \& Bonpl.: Lecythidaceae). Theoretical and Applied Genetics 76, 929-932.

Ortiz, E.G., 2002. Brazil nut (Bertholletia excelsa). In: Shanley, P., Pierce, A.R., Laird, S.A., Guillen, A. (Eds.), Tapping the Green Market: Certification \& Management of Non-timber Forest Products. Earthscan Publications Ltd., London, UK, pp. 61-74.

Peres, C.A., Baider, C., 1997. Seed dispersal, spatial distribution and population structure of Brazilnut trees (Bertholletia excelsa) in southeastern Amazonia. Journal of Tropical Ecology 13, 595616.

Peres, C.A., Baider, C., Zuidema, P.A., Wadt, L.H.O., Kainer, K.A., Gomes-Silva, D.A.P., Salomão, R.P., Simões, L.L., Francisiosi, E.R.N., Valverde, F.C., Gribel, R., Shepard Jr., G.H., Kanashiro, M., Coventry, P., Yu, D.W., Watkinson, A.R., Freckleton, R.P., 2003. Demographic threats to the sustainability of Brazil nut exploitation. Science 302, 2112-2114.

Peters, C.M., 1996. The ecology and management of non-timber forest resources World Bank Technical Paper 322, The World Bank, Washington, D.C., USA.

Peto, R., Peto, J., 1972. Asymptotically efficient rank invariant procedures. Journal of the Royal Statistical Society A135, 185207.

Prance, G.T., 1976. The pollination and androphore structure of some Amazonian Lecythidaceae. Biotropica 8, 235-241.

Quinn, G.P., Keough, M.J., 2002. Experimental Design and Data Analysis for Biologists. Cambridge University Press, Cambridge, UK.

Rosas, G.K.C., 2006. Pressão de caça, abundância, densidade e riqueza de mamíferos em duas áreas de coleta de castanhado-brasil situadas no sudoeste do Estado do Acre, Brasil. M.Sc. Thesis, Universidade Federal do Acre, Acre, Brazil.

SAS Institute, Inc., 2004. SAS, Version 9.1. Cary, NC, USA.

Serrano, R.O.P., 2005. Regeneração e estrutura populacional de Bertholletia excelsa H. B. K. em áreas com diferentes históricos de ocupação, no Vale do Rio Acre (Brasil). M.Sc. Thesis, Universidade Federal do Acre, Acre, Brazil.

Silvertown, J., 2004. Sustainability in a nutshell. Trends in Ecology and Evolution 10, 276-278.

Stoian, D., 2005. Making the best of two worlds: rural and periurban livelihood options sustained by nontimber forest products from the Bolivian Amazon. World Development 33, 1473-1490.

Stone, S.S., 2003. From tapping to cutting trees: participation and agency in two community-based timber management projects in Acre, Brazil. Ph.D. Dissertation, University of Florida, Gainesville, Florida, USA.

Terborgh, J., 1999. Requiem for Nature. Island Press, Washington, DC, USA. 
Ticktin, T., 2004. The ecological implications of harvesting nontimber forest products: a review. Journal of Applied Ecology 41, 11-21.

Vander Wall, S.B., Kuhn, K.M., Beck, M.J., 2005. Seed removal, seed predation, and secondary dispersal. Ecology 86 (3), 801-806.

Viana, V.M., Mello, R.A., Moraes, L.M., Mendes, N.T., 1998. Ecologia e manejo da castanha do Pará em reservas extrativistas de Xapurí, Acre. In: Gascon, C., Moutinho, P. (Eds.), Floresta Amazônica: Dinâmica, regeneração e manejo. Ministério da Ciência e Tecnologia. Instituto Nacional de Pesquisa da Amazônia, Manaus, Amazonas, Brazil, pp. 277-292.

Vieira, S., Trumbore, S., Camargo, P.B., Selhorst, D., Chambers, J.Q., Higuchi, N., 2005. Slow growth rates of Amazonian trees: consequences for carbon cycling. Proceedings of the National Academy of Sciences 102, 18502-18507.

Wadt, L.H.O., Kainer, K.A., Cartaxo, C.B. da C., Nunes, G.M., Leite, F.M.N., Gomes-Silva, D.A.P., Sousa, M. de M.M., 2005b. Manejo da castanheira (Bertholletia excelsa) para produção de castanha- do-brasil. Secretaria de Extrativismo e Produção Familiar, Documento Técnico, 3, Acre, Brazil.

Wadt, L.H.O., Kainer, K.A., Gomes-Silva, D.A.P., 2005a. Population structure and nut yield of a Bertholletia excelsa stand in Southwestern Amazonia. Forest Ecology and Management 211, 371-384.

Wallace, R.H., 2004. The effects of wealth and markets on rubber tapper use and knowledge of forest resources in Acre, Brazil. Ph.D. Dissertation, University of Florida, Gainesville, Florida, USA.

Zuidema, P.A., Boot, R.G.A., 2002. Demography of the Brazil nut tree (Bertholletia excelsa) in the Bolivian Amazon: impact of seed extraction on recruitment and population dynamics. Journal of Tropical Ecology 18, 1-31.

Zuidema, P.A., 2003. Demography and management of the nut tree (Bertholletia excelsa). PROMAB (Programa Manejo de Bosques de la Amazonía Boliviana), Scientific Series 6, Riberalta, Bolivia. 